ISSN: 2146-3042

DOI: 10.25095/mufad.607189

Conventional and Islamic Indices: A Comparison on Performance Nevser Mine TÜKENMEZ ${ }^{* *} \quad$ Hasan ŞAKA $^{* * *} \quad$ Merve KIZGIN $^{* * * *}$

\title{
ABSTRACT
}

Islamic finance has become an important component of the international financial system. Although the very recent experience of Islamic finance was 40 years ago it is growing by $30 \%$ since 2000. Despite the growing interest in Islamic finance and Islamic capital markets, there are a few empirical studies that examine the performance of Islamic equity investing in the literature. As can be seen from the literature, the relations between Islamic and conventional indices vary according to the period and country of study. In some studies, it is suggested that Islamic indices have lower risk and volatility, but also lower return than the conventional indices in the periods of decline. In other studies, exact opposite results were obtained. However, when an overall assessment is made, it is widely regarded that Islamic indices are more stable under bear market conditions and more suitable for portfolio diversification.

The purpose of this study is to compare the return performances of Islamic and conventional indices. The paper studies the impact of Sharia s creening on the performance of an index. The paper aims to answer the following question: Do Islamic indexes achieve lower returnlevelswhencomparedt otheir counterparts?Accordingtothefindings of this study and in accordance with most of the literature, there is no significant difference between the returns of Islamic and conventional indices. Also when the mean returns are compared between Islamic indices and their counterparts, it's been observed that all of the Islamic indices show higher performance than their counterparts.

KeyWords: Islamic Finance, Islamic Indices, Sharia Screening, T-Test.

Jel Classification: $G 10$

\section{İslami ve Geleneksel Endeks Performanslarının Karşılaştırılması Üzerine Bir Araştırma \\ ÖZET}

İslami finans, uluslararası finans sisteminin önemli bir bileşeni haline gelmiştir. İslami finansın ilk ortaya çııışı 40 yıl öncesine dayanmasına rağmen, İslami finans uygulamaları 2000 yılından bu yana \% 30 artış göstermiştir. İslami finans ve İslami sermaye piyasalarına olan ilginin artmasına rağmen, literatürde İslami hisse senedi yatırımlarının performansını inceleyen az sayıda ampirik çalışma bulunmaktadır. Literatürden de görülebileceği gibi, İslami ve geleneksel endeksler arasındaki ilişkiler, çalışılan döneme ve ülkeye göre değişmektedir. Bazı çalışmalarda, Íslami endekslerin risk ve oynaklığının daha düşük olduğu, ancak düşüş dönemlerinde geleneksel endekslere göre daha düşük getiri elde sağladıkları öne sürülmektedir. Diğer çalışmalarda tam tersi sonuçlar elde edilmiştir. Bununla birlikte, genel bir değerlendirme yapıldı̆̆ında, İslami endekslerin ayı piyasası koşullarında daha istikrarlı ve portföy çeşitlendirmesi için daha uygun olduğu yaygın olarak kabul edilmektedir.

$\mathrm{Bu}$ çalışmanın amacı, İslami ve geleneksel endekslerin getiri performanslarını karşılaştırmaktır. Çalışma, Şeriat taramasının bir endeksin performansı üzerindeki etkisini incelemektedir. Çalışma şu soruyu cevaplamayı hedeflemektedir: Islami endekslerin getirileri emsallerine göre daha düşük mü kalmaktadır?Çalışmanın bulgularına ve literatürün çoğuna göre, İslami ve geleneksel endekslerin getirileri arasında anlamlı bir fark yoktur. Ayrıca, İslami endeksler ve emsalleri ortalama getirilerine göre karşılaştırıldığında, tüm İslami endekslerin analiz dönemi itibariyle emsallerinden daha yüksek performans gösterdiği görülmüştür.

Anahtar Kelimeler: Islami Finans, Islami Endeksler, Şeriat Tarama, T-Testi.

Jel Sınıflandırması: G10

Makale Gönderim Tarihi: 01.06.2019

Makale Kabul Tarihi: 01.08.2019

Makale Türü: Araştırma Makalesi

\footnotetext{
${ }^{*}$ This paper is presented at the ISAF 2019, 1-4 May 2019, Bursa, Turkey.

*** Prof., Dokuz Eylul University, FEAS, Turkey, mine.tukenmez@deu.edu.tr, ORCID NO: 0000-0001-54739773

${ }^{* * *}$ PhD Student, Dokuz Eylül University, Graduate School of SocialSciences, Turkey, sakahasann@hotmail.com, ORCID NO: 0000-0002-0573-1262

PhD Student, Dokuz Eylül University, ,Graduate School of Social Sciences, Turkey, mervve.kizgin@gmail.com, ORCID NO: 0000-0001-7441-5039
} 


\section{INTRODUCTION}

Islamic finance has become an important component of the international financial system. Although the very resent experience of Islamic finance was 40 years ago it is growing by $30 \%$ since 2000 .

Capital markets under Islamic law (Sharia) has shaped world financial system in less than two decades in a response to a strong demand from Muslim community worldwide to have an alternative financial system more resistant to moral hazard. In addition to increasing the opportunities for investors with religious sensitivities to invest in the capital markets, Islamic stocks and Islamic funds, an alternative to the conventional investment instruments, have started to be considered by investors also outside the Islamic geography as alternatives for hedging. According to an important part of existing literature Islamic capital market instruments bearless risk during financial crisis yearsand even higher profitability.

\section{THE FUNDAMENTALS OF ISLAMIC FINANCE}

The basic principle of Islamic finance, Tawheed, is to accept that the whole universe is created and controlled by God. Although the belief in Tawheed is the basic principle of Islamic finance, it has other principles that have a direct impact on financial instruments and institutions. While some of these principles are in the form of prohibition, some of them are implicitly imposed in relation to prohibitions and other principles. In this context, i the basic principles of Islamic finance can be listed in the figure below:

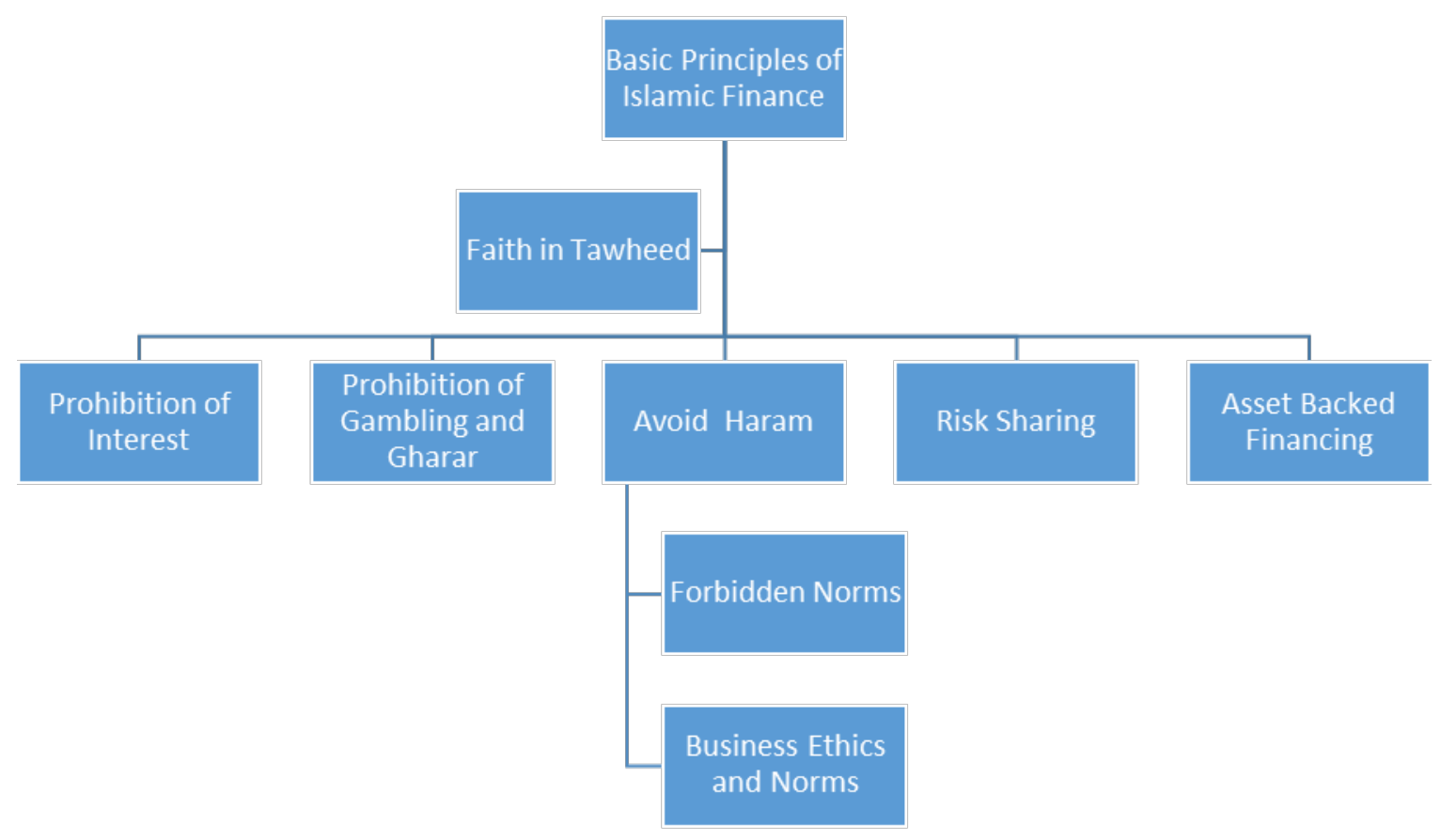

Source:Yanpar, 2014:55

Figure 1: Principles of Islamic Finance 
The most common known rule of Islamic religion related to economic life is related to interest, and this rule is one of the fundamental paradigms of the economic approach of Islamic religion. The concept of interest is now used for the term of 'riba' used in the Qur'an. Islamic jurists have not come to a clear consensus on the meaning of interst and whether many types of interest used in the modern world meet the word 'riba' in the Qur'an.

After the ban on interest in Islamic finance, gharar is one of the most important prohibitions. Garar is essentially a valid concept in trade contracts and refers to the uncertainty arising from the sale of goods, the price, the maturity, whether or not being able to deliver. The most significant effect of Garar in Islamic finance is that some Islamic jurists objected to the use of some derivative instruments, especially the futures and options, in the Islamic financial system.

Islam religion completely prohibits gambling. The ban on gambling takes place in two places in the Quran; Surah Al-Baqara in the $219^{\text {th }}$ verse and the Surah Maidah verses $90-91$. Gambling is increasingly prohibited in these verses.

There are a number of important prohibitions on the daily life of Islam. Most of these are prohibitions on consumption of alcohol and pork. It is possible to add some areas such as tobacco products, drugs and adultery to these two basic prohibitions. Commercial activities carried out on these issues are also prohibited by Islam.

One of the most important issues in which Islamic finance is separated from the interest-based system is business ethics and norms. Although it is not claimed that there is no business ethics in the interest-based system, it is also clear that there is no serious punishment or control mechanism for unethical behavior either. However, in terms of Islamic finance, the situation is different. As they are founded on the rules of Islam, there is no liberty for institutions in Islamic finance to abide by these principles (Yanpar,2014: 63).

Islam has adopted the principle of spreading economic blessings and burdens in a balanced manner to the society. However, it also prohibited spreading of interest by means of interest-based instruments. In other words, Islam religion points to a certain aspect in the financial sense: partnership based on risk sharing

A risk-based partnership is a profit-loss partnership. This system, which is based on the principle of taking a share from profit or loss which may be certain as a result of economic activity, instead of certain fixed interest, ensures that the parties participate not only in gains but also in losses.

One of the most significant features of Islamic finance is its being based on an asset, in other words, based on a real product, property or value-based financing. In terms of Islamic law, money is not accepted as a commodity trade. That is why Islamic finance is always based on non-liquid assets (real assets). In other words Islamic finance is based on commodity trading. 


\section{ISLAMIC CAPITAL MARKETS}

The Islamic capital market has gained importance since the beginning of the 1980s. In the Middle East, the group that has been enriched with oil revenues has begun to look for ways to evaluate their wealth in accordance with Sharia. Their demands led to the development of Islamic capital markets as well as Islamic banking. The main instruments of the Islamic capital markets are sharia-compliant stocks, sukuk and sharia-compliant investment funds.

Sharia-compliant stocks are traded in Islamic stock markets in accordance with the Sharia. From a theoretical standpoint at Sharia provisions and financial markets, it is clear that investment in stock markets or equities should be the primary means of preference in Islamic finance for stock investments can adapt directly to Sharia due to their structural characteristics.

On the other hand, it is clear that the Islamic law and the basic principles of Islamic finance must be obeyed in Islamic capital markets. Therefore, it is clear that Islamic stock markets must also comply with the basic principles of Islamic finance.

As mentioned before, one of the basic principles of Islamic finance is the principle of avoiding haram and it has been stated that some basic elements such as alcohol, pig and gambling cannot be introduced into Islamic finance practices. In addition to these principles of which all of the Islamic jurists agree, certain types of transactions that have become customary in the classical finance, in particular in equity transactions, cannot be reconciled with the principles of Islamic finance by some Islamic jurists.

These transactions should be examined under two main headings.

1)Loan and Leveraged Capital Market Transactions (Margin Trading): Credit capital market transactions known as Margin Trading is an investment strategy which is not suitable for Islamic finance since it involves interest due to its nature. Also, in some sources, it is stated that both credit capital market transactions and leveraged financial transactions should be avoided because they contain too much uncertainty.

2)Day Trading: The value of a company is (theoretically) equal to the present value of future cash flows. Since the value of a company cannot naturally increase instantaneously, intraday transactions are put in the category of transactions involving gambling or garages by Islamic jurists, and therefore regarded as an unacceptable investment approach in Islamic finance.

The second dimension of Islamic capital markets is the compliance of financial instruments to Sharia. As it will be clear that, all shares traded in the stock exchanges, are not eligible to invest in terms of the Sharia provisions. For example, in addition to enterprises dealing in sectors that are not compatible with Sharia, such as alcohol or weapon production, there are many enterprises that use interest-bearing loans or interest-bearing financial assets. For this reason, an equity or a company needs to be assessed in terms of Islamic rules in order to gain the status of investable in the Islamic stock market. 
However, doing such a comprehensive analysis is quite laborious and costly for individual investors as well as institutional investors. In this context, the Islamic finance industry has established some mechanisms to assess the compliance of companies with the sharia. Today, these mechanisms are called Sharia filtering methods

Sharia filtering mechanisms are based on examining the activities of companies in terms of compliance with Sharia and publicizing it. This is done by two different methods. The first is the index application. In this application, the companies are subject to evaluation in terms of compliance with the provisions of Sharia, and in case of positive results, they are included in the relevant index. The second is the Islamic investment funds, which are actually based on the practice index. These funds use these Islamic stock indices and also make direct investments in line with the rules by directly reviewing the companies themselves. Today there are a large number of generally accepted Islamic indexes in the world.

The first major Islamic index, Dow Jones Islamic Market Indexes (Dow Jones Islamic Market Indexes - shortened as DJIM), was created in 1999. Today, there are more than one hundred different business indices of various institutions such as FTSE Group, MSCI Barra, BSE TASIS, Global GCC and Standard \& Poor's.

On the other hand, the filtering process of each Islamic index differs from one another. This is the difference that includes different perspectives on the provisions of the Sharia. In this context, both investors and fund managers need to examine the criteria used in the filtering process carefully andthen choose the indices that are approved by the Islamic Law School they adopt.

As there are many Islamic indices present in today's capital markets using different perspectives on the provisions of the Sharia in their filtering processes, filtering principles of the six Islamic indices used in this study will be mentioned briefly in this section.

\subsection{FTSE Bursa Malaysia HijrahSharia Index}

This index comprises the largest 30 companies by full market capitalisation of the FTSE Bursa Malaysia EMAS Index that are in compliance with Yasaar and the SAC screening methodology.

Companies in the index are screened by the Malaysian Securities Commission's Shariah Advisory Council (SAC) and the leading global Shariah consultancy, Yasaar Ltd, against a clear set of guiding principles.

\section{Business Activity Screening:}

Constituents of the index are not permitted to be involved in any of the following core activities: banking or any other interest-related activity, such as lender and brokerages, but excluding Islamic financial institutions; alcohol; tobacco; gaming; arms manufacturing; life insurance; and, pork and non-halal production, packaging and processing or any other activity related to pork and non-halal food. 
Companies that meet the following criteria, which are assessed under Sharia principles and commonly accepted philosophies, are also excluded from the index:

- Ratios of debt and debt service in combination that are unacceptable and indicative of an inappropriate use of leverage relative to their assets.

- Income from cash or near cash equivalents or inappropriate levels of receivables to assets.

- Liquid assets to illiquid assets that exceed the percentages permitted.

- Cash and cash equivalents to total assets that exceed the percentage permitted.

(www.ftse.com)

\subsection{FTSE Japan 100 Sharia Index}

The FTSE Japan 100 Sharia Index has been designed to be used as the basis of Sharia compliant investment products that meet the requirements of Islamic investors in Japan and internationally. Independent screening is carried out by Yasaar Limited, an organization with a global network of expert Sharia scholars. Their approach is described below. Using the Large and Mid. Cap stocks from the FTSE Global Equity Index Series as a base universe, the top 100 Sharia-compliant Japanese constituents by market capitalization are then selected to form the FTSE Japan 100 Sharia Index.

\section{Business Activity Screening:}

Initially, companies involved in any of the following activities will be filtered out as non-Sharia compliant:

- Conventional finance (non-Islamic banking, finance and insurance, etc.);

- Alcohol;

- Pork related products and non-halal food production, packaging and processing or any other activity related to pork and non-halal food;

- Entertainment (casinos, gambling and pornography);

- Tobacco; weapons, arms and defense manufacturing.

\section{Financial Screening}

The remaining companies are then further screened on a financial basis. The following financial ratios must be met for companies to be considered Shariah-compliant:

- Debt is less than 33.333\% of total assets;

- Cash and interest bearing items are less than 33.333\% of total assets; 
- Accounts receivable and cash are less than $50 \%$ of total assets;

- Total interest and non compliant activities income should not exceed 5\% of total revenue.

\subsection{NIFTY 500 Sharia Index}

The NIFTY 500 Index is the parent index to NIFTY500 Sharia Index. This index does not have fixed number of companies. Constituents of the parent index which are Sharia compliant are part of NIFTY500 Sharia Index. NSE Indices Limited has contracted with Taqwaa Advisory and Sharia Investment Solutions (TASIS) to provide the Sharia screens and filter the stocks based on these screens.

\section{Business Activity Screening:}

Activities which are not permitted under Sharia are those which involve engaging in interest earning businesses or in those businesses which are mostly harmful to human society and disallowed by Sharia. Thus companies engaged in promoting promiscuity, violence, vulgarity and businesses affecting the environment are also considered Sharia non-compliant. Hence all companies which are primarily into the following activities are screened out on the business parameter.

- Conventional financial services such as banks, insurance companies, finance and investment companies, stock broking etc.

- Production, sale and marketing of non-Halal food and beverages such as Pork, Alcohol, Tobacco and such other items etc.

- Companies involved in production or distribution of vulgar entertainment, such as film and other recreational activities where vulgarity, promiscuity is a part and parcel of the business undertaken / promoted

- Hotels and restaurants (providing non-Halal products or entertainment)

- Gambling, Narcotic drugs, etc.

\section{Financial Screening:}

To remain on the conservative side from a Sharia adherence perspective, TASIS has adopted financial screening norms which are more conservative than those followed by its peers and also justified by empirical studies of the Indian environment:

- Interest based-debt should be less than or equal to 25\% of Total Assets.

- Interest income plus returns (currently considered @8\%) from interest-based investments should be less than or equal to $3 \%$ of the total income. 
- Receivables plus cash and bank balances should be less than or equal to $90 \%$ of Total Assets (www.nseindia.com).

\subsection{Participation 50 Index}

Participation 50 Index is a stock index formed of stocks traded at Borsa Istanbul National Market and conforming to Participation Banking principles.

Companies to be admitted to Participation 50 Index are determined in two stages, namely main area of activity and financial criteria. As specified in detail below, during the first stage companies traded at National Market, Real Estate Investment Trusts traded at Corporate Products Market and Venture Capital Investment Trusts are analyzed according to their areas of activity and the Main List is prepared with the exclusion of non-eligible companies. In the second stage, Main List companies are reviewed according to their financial rates and activities and the List of Index Companies takes its final shape with the exclusion of non-eligible companies.

\section{Business Activity Screening:}

Main List companies are selected from those not taking the following fields as their main area of activity:

- interest-based financing, trade, services, intermediation (banking, insurance, financial leasing, factoring and other interest-based activities),

- alcoholic beverages,

- gambling, games of chance,

- pork and similar food,

- press, publications and advertisement,

- tourism, entertainment,

- tobacco products,

- futures gold, silver and currency trade.

\section{Financial Screening:}

Companies in the Main List are subjected to elimination by their financial rates. Accordingly, companies are required to meet the following conditions in order to be able to be admitted to the index:

- The rate of total interest-bearing debt of companies to market capitalization shall be lower than $30 \%$; 
- The rate of interest-bearing cash and securities to market capitalization shall be lower than $30 \%$

- The rate of income from above mentioned fields to total income shall be lower than $5 \%$.

\subsection{FTSE Shariah USA Index}

This index is designed to represent the country level performance of the largest and most liquid Sharia compliant companies based on the FTSE GEIS US Large and Mid. cap Index companies. FTSE Sharia USA Index, which comprises 241 mid- and large-cap U.S.traded shares.

\subsection{MSCI World Islamic Index}

The MSCI World Islamic Index reflects Sharia investment principles and is designed to measure the performance of the large and Mid. cap segments of the 23 Developed Markets (DM) countries that are relevant for Islamic investors. The index, with 505 constituents applies stringent screens to exclude securities based on two types of criteria: business activities and financial ratios derived from total assets.

\section{Business Activity Screening:}

The methodology for the MSCI Global Islamic Indexes follow Sharia investment principles and does not allow investment in companies that are directly active in, or derive more than $5 \%$ of their revenues from such business activities as alcohol, tobacco, pork-related products, conventional financial services, defense/weapons, gambling, or adult entertainment. In addition, the MSCI Global Islamic Indexes do not allow investment in companies deriving significant income from interest or companies that have excessive leverage.

\section{Financial Screening:}

MSCI uses three financial ratios to screen for such companies: 1) total debt over total assets; 2) the sum of a company's cash and interest-bearing securities over total assets; and 3) the sum of a company's accounts receivables and cash over total assets. None of these financial ratios may exceed 33.33\%. Finally, if a company derives part of its total income from interest income and/or from prohibited activities, Sharia investment principles state that this proportion must be deducted from the dividends paid out to shareholders and given to charity. MSCI therefore applies a dividend adjustment factor to all reinvested dividends (www.msci.com, 2019).

\section{LITERATURE REVIEW}

Despite the growing interest in Islamic finance and Islamic capital markets, there are a few empirical studies that examine the performance of Islamic equity investing in the literature. Among the studies on Islamic equity indices an important part of the studies concentrated on the comparison of Islamic and conventional market indices in terms of performance criteria. In several studies it has been observed that there is no statistically 
significant difference between the performances of Islamic and conventional indices: Ahmed and Ibrahim (2002), Hussein (2004), Abdullah et al (2007), Hassan and Girard (2011), Lobe et al (2012), Albaity and Mudur (2012). However; differences of performance have been observed during bear and bull market periods: Hussein (2004) both stated that Islamic indices perform better during bull market periods and Lobe et al (2012) on the other hand, and Rajjague (2010), and more recently Ito et al (2014), concluded that Islamic indices perform better especially during crisis (bear market) periods.

In a study by Ata Bugan (2015) performances of Islamic and conventional Dow Jones and Morgan Stanley indices created for Turkey have been compared for crisis periods, by using T-test, It has been observed that there is no statistically significant difference between the returns of indices for each period.

Ahmad and Ibrahim (2002) compared the performance of Kuala Lumpur Shariah Index (KLSI) and Kuala Lumpur Composite Index (KLCI) for the period of 1999 to 2002. They found lower risk - adjusted returns for KLSI although higher risk for KLCI.

Albaity and Ahmad (2008) also have analyzed the performance of (KLSI) against the (KLCI) over a period from 1999 to 2005. Their findings suggested absence of significant statistical differences in risk-adjusted returns between the indices, although KLSI Had lower returns, but it also had lower risk exposure than the KLCI.

Hassan and Girard (2011) examined the performance of Dow Jones Islamic Indices with their counterparts using measures such as Sharpe, Treynor and Jensen from 1996 to 2005 and found no statistically significant difference in performance between the Islamic and conventional indices.

Pranata and Nurzanah (2015) studied the performance and volatility of Jakorta Islamic indec (JII) and compared it to its conventional counterpart (LQ45) by adopting capital Asset Prising Model (CAPM) and beta calculation. They found no statistical difference between the indices, JII less volatile than LQ45.

Rana and Akhter (2015) compared the performances of KMI-30 Islamic index with the KSE-100 conventional index of Pakistan capital market and did not find a statistically significant difference between the returns of the indices.

Ho et al (2014) examined the index returns of Islamic and conventional indices in the US, UK, France, Switzerland, Hong-Kong, Malaysia, Indonesia and India and resulted that Islamic indices performed better in times of crisis. According to the findings of the study, Islamic indicesare less affected by financial crisis due to their low beta values and low volatility. However, after the crisis period, it was found that Islamic indices performed lower than expected and some conventional indices yielded returns over Islamic ones.

El -Khamlichi et al (2014) studied the relationship between Dow Jones, Financial Times, Standard and Poors, Morgan Stanley's Islamic and conventional indices and both types of indices gave similar productivity. The results of cointegration analysis revealed that Financial Time's and Morgan Stanley’s Islamic and conventional indices are integrated. 
According to the findings of the study, cointegrated indices are not favorable in terms of portfolio diversification since they act together in the long term.

AltinveCaba (2016) studied the return performance of Borsa Istanbul Participation indices and BIST 100 index and concluded that Paricipation indices yielded a higher return.

Sakarya et al (2017) compared the return performance of BIST Participation 30 index with the Corporate Governance and BIST 50 indices respectively by Sharpe, Treynor, Jensen criteria for the 2011-2016 period. The results showed a higher return performance of Participation 30 index relative to other two indices.

$\mathrm{Al}$ - Khazali et al (2014) compared 9 Dow Jones Islamic and conventional indices for 2007 - 2012 period. According to the study; European, American and World Islamic indices showed higher performance than conventional indices during global crisis period.

Dharani and Natarajan (2011) analyzed the performances of Islamic and conventional indices in India. The T-test has been used and average returns of NIFTY Shariah Index were compared with conventional Nifty index. The found no difference between average daily returns of both indices.

As presented above, most researchers have made comparison studies between the performances of Islamic and non-Islamic portfolios.

Opponents of Islamic investing argue that unscreened benchmarks may outperform Islamic investment since using Shariah criteria may cause additional screening and monitoring costs and availability of a smaller investment universe and restricted potential for diversification (Temper, 1991). As can be seen from the literature, the relations between Islamic and conventional indices vary according to the period and country of study. In some studies, it is suggested that Islamic indices have lower risk and volatility, but also lower return than the conventional indices in the periods of decline. In other studies, exact opposite results were obtained. However, when an overall assessment is made, it is widely regarded that Islamic indices are more stable bear market conditions and more suitable for portfolio diversification.

\section{PURPOSE OF THE STUDY}

The purpose of this study is to compare the return performances of islamic and conventional indices. The paper studies the impact of Shariah screening on the performance of an index. The paper aims to answer the following question: Do Islamic indexes achieve lower return levels when compared to their counterparts? study;

Hypothesis: Taking this aim into consideration, the following hypothesis is set for the

$\mathbf{H}_{\mathbf{0}}$ : There is not statistically significant difference between the returns of Islamic index and its conventional counterpart. 


\section{METHODOLOGY AND DATA}

To attain the objective of the study six pairs of Islamic and conventional indices which cover 5 countries (United States, Turkey, Malaysia , Japan, India) and one pair of Islamic and conventional index that cover the World are chosen. The index selection was made by taking the availability of data into consideration. The list of the indices studied use in the study is presented below:

\begin{tabular}{lll}
\hline Country of Origin & Conventional Indices & Islamic Indices
\end{tabular}

Malaysia FTSE Bursa Malaysia Emas Ind. FTSE Bursa Malay. Hijrah In

Japan

Turkey

India

USA BIST 100

NIFTY 500 Index

FTSE 100

World MSCI All Country World

\author{
Participation 50 Index \\ NIFTY 500 Shariah \\ FTSE Shariah USA \\ MSCI World Islamic Index
}

The return of each index is calculated on monthly basis by the following formula;

$\mathbf{R}_{\mathrm{i}, \mathrm{t}}=\ln \left(\mathrm{P}_{\mathrm{i}, \mathrm{t}} / \mathrm{P}_{\mathrm{i}, \mathrm{t}-1}\right)$

$\mathbf{R}_{\mathrm{i}, \mathrm{t}}=$ raw return for index $\mathrm{i}$ for the time $(\mathrm{t})$

$\mathbf{P}_{\mathrm{i}, \mathrm{t}}=$ price of index $\mathrm{i}$ at time $(\mathrm{t})$

$\mathbf{P}_{\mathrm{i}, \mathrm{t}-\mathrm{1}}=$ price of index i at time ( $\left.\mathrm{t}-1\right)$

The purpose of the study is only limited to determining if there is a significant difference between the returns of Islamic and conventional index pairs. In order to achieve that parametric T-test is used. Ttest is used to test whether there is a difference between the returns of indices.

All data is derived from investing.com. Our data is from Jan 2010 to January 2019 expect for Participation 50 index which is launched in August 2014.

\section{RESULTS}

The descriptive statistics for each index and correlations coefficient between the Islamic indices and their counterparts are presented on Table 1.

Table 1. Descriptive Statistics and Correlations Between Conventional and Islamic Indices

\begin{tabular}{|c|c|c|c|c|c|}
\hline Index & Minimum & Maximum & Mean & Std. Dev & Correlations \\
\hline Bist 100 & -.102702 & .131277 & .00489007 & .055904 & \multirow{2}{*}{0.928} \\
\hline Katılım 50 & -.093440 & .109527 & .00537573 & .048026 & \\
\hline FTSE Japan & -.117015 & .118696 & .00499008 & .050255 & \multirow{2}{*}{0.976} \\
\hline FTSE Japan Shariah & -.117555 & 109650 & .00545390 & .048267 & \\
\hline FTSE USA & -.096144 & .102554 & .00852394 & .036151 & \multirow{2}{*}{0.986} \\
\hline FTSE USA Shariah & -.098441 & .097896 & .00689835 & .035634 & \\
\hline MSCI World & -.103356 & .100886 & .00499709 & .038703 & \multirow{2}{*}{0.671} \\
\hline MSCI World Islamic & -.072048 & .094948 & .00599805 & .032092 & \\
\hline NIFTY 500 & -.110378 & .126487 & .00715821 & .045932 & \multirow{2}{*}{0.909} \\
\hline NIFTY 500 Shariah & -.104058 & .099294 & .00799392 & .039965 & \\
\hline FTSE Malaysia & -.080330 & 078924 & .00266299 & .027367 & \multirow{2}{*}{0.934} \\
\hline FTSE Malaysia Shariah & -.089205 & 075512 & .00337453 & 027841 & \\
\hline
\end{tabular}

As shown on Table 1 average monthly returns for all indices are positive. Of all the indices FTSE USA conventional has the highest average return for the period of analysis 
whereas FTSE Bursa Malaysia has the lowest. Taking the Islamic index into consideration, its observed that NIFTY 500 Shariah index has the highest performance and FTSE Bursa HijrahShariah has the lowest return performance. When the mean returns are compared between Islamic indices and their counterparts, it's been observed that all of the Islamic indices show higher performance than their counterparts. When the comparison is made for maximum returns an opposite result is observed; all of the conventional indices showing higher performance than their Islamic counterpart. In terms of dispersion of the returns, it's observed that standard deviation of the conventional indices is higher than Islamic indices in 5 of the 6 cases. The 6th market is Malaysia where standard deviations of both indices are very close to each other. This result is not consistent with the common argument that Islamic stocks bear higher risk than their conventional counterparts.

Table 1, reports the correlation coefficient between conventional and Islamic indices. Correlations measure the strength of linear relationship between two variables. As been observed, all the pairs have a very high positive relationship (corrcoeff $>0.9$ ). The only pair of indices with a moderate relationship is MSCI All World and World Islamic, as the conventional index covers 2,491 stocks, but the Islamic counterparts has 505 constituents.

Table 2. T-Test of Mean Differences between Returns of Conventional and Islamic Indices

\begin{tabular}{|c|c|c|}
\hline Paired Differences & T-Value & P-Value \\
\hline Bist 100- Katılım 50 & -0.167 & 0.868 \\
\hline FTSE Japan- FTSE Japan Shariah & -0.438 & 0.662 \\
\hline FTSE USA- FTSE USA Shariah & -2.802 & 0.006 \\
\hline MSCI World- MSCI World Islamic & -0.355 & 0.724 \\
\hline NIFTY 500-NIFTY 500 Shariah & -0.452 & 0.652 \\
\hline FTSE Malaysia-FTSE Malaysia Shariah & -0.722 & 0.472 \\
\hline
\end{tabular}

Table 2 presents the results of the T-test between Islamic and conventional indices. The result of the P-value indicate that there is no significant difference between the returns of Islamic and conventional indices and 5\% and 10\% level, expect for FTSE USA - FTSE USA Sharia index pair. This result is consistent with the results of Hassan and Girard (2011), Dharani and Natarajan (2011) and Albaity and Ahmad (2008). However there is a significant difference between conventional and Islamic indices of FTSE USA.

\section{CONCLUSION}

Islamic Finance is known as a very flexible and less risky activity. This helped it to develop rapidly and to meet different demands. In addition to the financial windfall that it represents, Islamic Finance has a strong credibility, strengthened during the last economic crisis. Islamic Finance is present, for years, in the United States, European countries, in the countries of Southeast Asia and the Gulf countries, and it has begun to exist in other Arab countries since 2010 .

Islamic indices are launched to open the opportunities for investment in equity market for the investors according to their ethical commitment. This paper attempts to answer the 
question whether these indices have the same return performance as their conventional counterparts or not.

As can be seen from the literature, the relations between Islamic and conventional indices vary according to the period and country of study. However, when an overall assessment is made, it is widely regarded that Islamic indices are more stable under bear market conditions and more suitable for portfolio diversification.

According to the findings of this study and in accordance with most of the literature, there is no significant difference between the returns of Islamic and conventional indices. Also when the mean returns are compared between Islamic indices and their counterparts, it's been observed that all of the Islamic indices show higher performance than their counterparts.

These results can be explained mostly with the absence of financial sector in Islamic indices. For example, Most S\&P and Dow Jones Indices Sharia-compliant benchmarks outperformed their conventional counterparts through the end of September 2016, with financials - which is largely absent from Islamic indices-significantly underperforming and information technology — which tends to be overweight in Islamic indices-performing well . This marked a reversal during the last quarter of 2016, where a surge in the financial sector caused Sharia-compliant benchmarks to lag.

Most S\&P and Dow Jones Sharia-compliant benchmarks outperformed their conventional counterparts for the year 2017 as well as information technology companies which tend to be overweight in Islamic Indices - gained a whopping $39.4 \%$ beating the overall market by a wide margin, and financials - which are underrepresented in Islamic indices experienced some weakness. One notable exception to the 2017 trend was in the Middle East, where conventional and Islamic benchmarks tracked closely together, since technology stocks are not a meaningful portion of the regional market.

Most S\&P and Dow Jones Sharia-compliant benchmarks outperformed their conventional counterparts through the first half of 2018 as financials - which are largely absent from Islamic indices - lagged the market by a wide margin. The strong performance of information technology and healthcare stocks - which tend to be overrepresented in Islamic indices - also contributed to the outperformance of Islamic benchmarks.

\section{REFERENCES}

Abdullah, F - Hassan, T. - Mohamad, S. (2007), Investigation of performance of Malaysian Islamic unit trust funds: Comparison with conventional unit trust funds. Managerial Finance, 33(2), 142-153.

Ahmad, Z. - Ibrahim H. (2002), A Study of Performance of The KLSE Shariah Index’,Malaysian Manage.J. , pp. 25-34

Alam, N. - Rajjaque, M. S. (2010), "Shariah-compliant equities: Empirical evaluation of performance in the European market during credit crunch", Journal of Financial Services Marketing, 15(3), pp.228-240. 
Albaity, Mohamed - Rubi, Ahmad (2008), "Performance of Syariah And Composite Indices: Evidence From Bursa Malaysia”, Asian Academy of Management Journal of Accounting and Finance, 4(1), pp.23-43.

Albaity, M. S. - Mudor, H. (2012), Return performance, Cointegration and short run dynamics of Islamic and non-Islamic indices: evidence from the US and Malaysia during the subprime crisis. Atlantic Review of Economics, 1.

Altın, Hakan - Caba, Nihan (2016), “Borsa İstanbul’da İşlem Gören Katılım Endekslerinin Performanslarının Değerlendirilmesi”, Finansal Araştırmalar ve Çalışmalar Dergisi, 8(15), ss.229-248.

Al-Khazali, Osamah - HooiHooi, Lean - Anis, SAMET (2014), "Do Islamic Stock Indexes Outperform Conventional Stock Indexes? A Stochastic Dominance Approach”, Pacific-Basin Finance Journal, 28(2014),pp 29-46.

Ata, H.Ali - Bugan, M.Fatih (2015), 'Comparison of the Performances Islamic and Conventional Market Indices and their Causal Relationship,' International Journal of Business Management and Economic Research, Vol 6(6), pp.455-462

Dharani, M. - Natarajan, P. (2011), "Equanimity of Risk and Return Relationship between Shariah Index and General Index in India”, Journal of Economics and Behavioral Studies, 2(5), pp.213-222.

El- Khamlichi, Abdelbari - Sarkar, Morocco - Arouri, Mohamed - Teulon, Frédéric (2014), "Are Islamic Equity Indices More Efficient Than Their Conventional Counterparts? Evidence From Major Global Index Families”, The Journal of Applied Business Research, 30(4); 1137-1150.

Hakim, S. - Rashidian, M. (2004), "Risk and Return of Islamic Stock Market Indexes", Presented at the International Seminar of Nonbank Financial Institutions: Islamic Alternatives, Kuala Lumpur, Malaysia.

Hashim, Noor (2008), TheFtse Global Islamic and The Risk Dilemma. AIUB Bus Econ Working Paper Series, 08,http://orp.aiub.edu/WorkingPaper/WorkingPaper.aspx?year=2008.

Hassan, M. Kabir - Girard, Eric (2010), "Faith-Based Ethical Investing: The Case Of Dow Jones Islamic Indexes”, Islamic Economic Studies, 17(2); 1-31.

Ho - Fun, Catherine Soke Fun - Rahman, Nurul AfigahAbd - Yusuf, Noor Hafizha Muhamad - Zamzamin, Zaminor (2014), "Performance of Global Islamic versus Conventional Share Indices: International Evindence”, Pasific -Basin Finance Journal, 28(2014); pp.110-121.

Hussein, K.A. (2004), "Ethical Investment: Empirical Evidence from FTSE Islamic Index", Islamic Economic Studies, 12 (1), pp.21-40. 
Iqbal, Z. (1997), ‘Islamic Financial Systems’, Finance \& Development, pp.42-45.

Jawadi,Fredj - Jawadi, Nabila - Louhichi, Wael (2014), "Conventional and Islamic Stock Price Performance: An Empirical Investigation”, International Economics, 137(2014), pp.73-87.

Lobe, S. - Rößle, F. - Walkshäusl, C. (2012), The Price of Faith: Performance, Bull and Bear Markets, and Screening Effects of Islamic Investing Around the Globe. The Journal of Investing, 21(4), pp.153-164.

Pranata, Nika - Nurzanah, Nurzanah (2015), 'Conventional and Islamic Indices in Indonesia: A Comparison on Performance, Volatility, and The Determinants', Indonesian Capital Market Review, October

RANA, Muhammad Ejaz - Akhter, Waheed (2015), "Performance of Islamic and Conventional Stock Indices: Empirical Evidence from an Emerging Economy”, Center of Islamic Finance, COMSATS Working Paper, Pakistan.

Sakarya, Şakir - Yıldırım, HasanHüseyin - Yavuz, Mehmet (2017), $\begin{array}{llll}\text { "KurumsalYönetimEndeksiveKatılım } & 30 & \text { EndeksiileBist } & 50\end{array}$ Endeksi'ninPerformanslarınınDeğerlendirilmesi”, UluslararasıSosyalAraştırmalarKongresi (ISBN: 978-605-82729-0-3); 474-487.

Temper, J. (1991), "The Cost of Social Criteria", Pensions \& Investments, May 13,34.

Yanpar, Atila (2014) İslami Finans İlkeler, Araçlar ve Kurumlar, Scala Yayıncılık, İstanbul. www.ftse.com/products/downloads/FTSE_Bursa_Malaysia_Index_Series.pdf (26.02.20019) www.nseindia.com (26.02.2019).

www.msci.com/documents/10199 (26.02.2019) 